\title{
Access To Justice, Moral Distance And Changing Demands On Law
}

\section{Roger Cotterrell*}

This paper reflects theoretically on the concept of access to justice-focusing in turn on each of its limbs - the idea of justice and that of access. 'Justice' is considered here not philosophically but socio-legally in terms of a spectrum of types of justice-demands made in relation to law. The idea of 'access' is analysed by drawing on socio-legal theory concerned with the remoteness of lawmakers from citizens. The aim is to put the concept of access to justice into a wide theoretical context that highlights changing demands on law and new socio-legal conditions - especially those associated with contemporary multiculturalism and the increasingly significant transnational dimensions of law. The paper argues that these demands and conditions make such a wide view timely and necessary. It proposes that an analysis of relations of law and solidarity taken from Durkheimian sociology can help in clarifying the possibilities and limits of state receptiveness to access to justice demands.

Dans ce document, l'auteur expose ses réflexions théoriques sur le concept de l'accès à la justice en examinant à tour de rôle chacun de ses volets : l'idée de la justice et celle de l'accès. La " justice » est examinée ici non pas sur le plan philosophique, mais sur le plan sociojuridique en termes de spectre de types de justice ou de pressions exercées sur le système de droit. Quant à l'idée de l'«accès», l'auteur l'examine en s'inspirant de la théorie sociojuridique concernant le décalage entre le législateur et le citoyen. L'objectif est de présenter le concept de l'accès à la justice dans un vaste contexte théorique qui fait ressortir l'évolution des pressions exercées sur le droit et les nouvelles conditions sociojuridiques - notamment celles qui sont associées au multiculturalisme contemporain et aux dimensions transnationales de plus en plus importantes du droit. De l'avis de l'auteur, cette vaste perspective s'impose aujourd'hui en raison de l'ensemble de ces pressions et conditions. Qui plus est, une analyse des relations entre le droit et la solidarité, inspirée de la sociologie durkheimienne, pourrait permettre de mieux comprendre les possibilités et les limites de la réceptivité de l'État face aux pressions liées à l'accès à la justice.

* Anniversary Professor of Legal Theory, Queen Mary University of London, UK. This essay originated in a paper presented at the INTRALAW Colloquium on Access to Justice at Aarhus University in November 2019. I am grateful to Bettina Lemann Kristiansen and her colleagues for the invitation to present my ideas on that occasion, and to Rachael Mulheron for valuable comments on a draft of the essay. 


\section{INTRODUCTION}

This paper develops theoretical reflections on the concept of access to justice - focusing in turn on each of its limbs - the idea of justice and that of access. 'Justice' is considered here not philosophically but socio-legally in terms of a spectrum of types of justice-demands made by citizens in relation to law. And the idea of 'access' is analysed by drawing on socio-legal theory concerned with the remoteness of lawmakers from citizens. The aim is to put the concept of access to justice into a wide theoretical context that can reflect certain changing demands on law and new socio-legal conditions. The paper argues that these changing demands and conditions make such a wide view timely and necessary.

The term 'access to justice', as used in social policy and law reform contexts, has primarily meant two things in liberal democratic countries: (i) access to consistent, timely, fair and enforceable dispute resolution by state legal institutions or associated processes, in circumstances where local, relatively informal solutions to conflict do not exist, or are inaccessible, ineffective or inappropriate; and (ii) the ability to assert legal rights effectively, including in criminal processes and in welfare, consumer, employment, immigration, environmental, domestic relations and housing claims. So access to justice has focused primarily on dispute processing, conflict resolution and legal rights - and generally on ability to access the benefits of the rule of law. This has been the typical meaning of the term among lawyers and activists whose attention is on the state legal system, their hopes pinned on it.

Access to justice in this sense aims at 'justice through law' or 'justice as promised by law'. However, the concept remains ambiguous because of its explicit invocation not of law but of 'justice' - clearly a complex, often enigmatic idea. A similar issue arises with the idea of the 'administration of justice', which might perhaps be better called the administration of law - in the sense of state law's processes, institutions, officials, inputs and outputs. But here too, it is 'justice' that is invoked. Administration of justice and access to justice are interlinked, the latter suggesting gateways leading to the former.

So, we refer to access to justice although much of what access to justice focuses on is specifically access to law. Law is assumed to signify some means to justice. But the practices of access to justice are not usually concerned systematically with theories of justice, which tend to be left to philosophers. ${ }^{1}$ So, behind many law-focused, result-oriented strategies of access to justice stands - perhaps as a challenge or an inspiration - the infinitely debatable and variable notion of justice.

The second part of this paper examines the ambivalence of meanings of justice inherent in the idea of access to justice. In the third part, the concept of access is examined, being treated as an issue of communicative distance between legal regulators and the populations they seek to regulate. Finally, the general impact of certain wide-ranging changes in socio-legal conditions on access to justice (hereafter AJ) is considered, and the paper suggests that state recognition of justice-demands should, as a general principle, be guided by certain societal and communal needs for solidarity.

1 But see recently e.g. Marjorie Mayo et al, Access to Justice for Disadvantaged Communities (Bristol: Bristol University Press, 2014), invoking social justice theories, including that of John Rawls. 


\section{ACCESS TO JUSTICE AS A SPECTRUM OF EXPECTATIONS}

Justice may be claimed in relation to a legal system in different ways that reflect various degrees of confidence in what the system can provide, or about what might realistically be expected from it. ${ }^{2}$ This paper presumes the environments of modern western liberal legal systems that profess adherence to the rule of law. Types of justice claims in such contexts might be thought of in terms of a spectrum - perhaps from highest to lowest expectations for existing law. In this way it becomes clear that AJ activities, as currently practised, are part of a very extensive - indeed, potentially unlimited - range of justice-seeking strategies.

- At one level, demands may be merely for better access to existing legal institutions, rights and processes but with no attempt to change law itself - essentially the demand is for better knowledge of law or its contexts. So, for example, AJ demands may be for information about legal rights, procedures and remedies, for citizens' legal advice centres and community law centres, or translation services in legal contexts for non-native language speakers.

- At a second level, AJ may demand primarily legal procedural changes to improve access e.g. changes to court or policing procedures or to the professional regulation of lawyers, state-sponsorship of arbitration and mediation services and legal aid, facilitation of class actions, small claims and related processes, and formal complaints procedures applicable to lawyers and legal officials. ${ }^{3}$

- Again, at a third level, AJ may require primarily legal substantive change (or combinations of substantive and procedural ones) to create new individual protections and rights for citizens in general, as in laws against discrimination to ensure equal rights of access to the

2 For a few illustrations of the extreme diversity of contexts in which the concept of access to justice is explicitly invoked see Naomi Nichols, "The Social Organization of Access to Justice for Youth in 'Unsafe' Urban Neighbourhoods" (2018) 27 Soc \& Leg Stud 79 (young people's encounters with police in Toronto); Ralph Henham, "Conceptualizing Access to Justice and Victims' Rights in International Sentencing” (2004) 13 Soc \& Leg Stud 27 (relevance of moral values to effective assertion of rights in international criminal process); Christine Parker, Just Lawyers: Regulation and Access to Justice (Oxford: Oxford University Press, 1999), (legal profession regulation should link with communal justice and social movement politics to aid access to justice); Hazel Genn, Paths to Justice: What People Do and Think About Going to Law (Oxford: Hart, 1999), (perceived barriers to access to justice through legal processes and ways in which citizens deal with potential legal disputes, especially debt, consumer and employment problems, and with landlords and neighbours.)

3 In the UK, the Access to Justice Act 1999 focuses on public and private provision of legal services, rights of audience before courts, complaints against lawyers, appeals, and the organisation of magistrates' courts. A concept of 'overriding objective' in the Civil Procedure Rules, r 1.1(2) addresses efficient allocation of resources in civil justice. Procedural changes can also affect substantive rights, as where new procedures for access (e.g. in class actions) alter substantive claims that can be made, and even substantive law itself (e.g. of limitation periods). 
benefits of the liberal rule of law, to participation in society, or to safeguards for basic conditions of life. ${ }^{4}$

- AJ may also, fourthly, require differential legal treatment of populations, as in (substantive and/or procedural) legal action to support particular disadvantaged or marginalised population groups, giving their members special (temporary or permanent) legal statuses, opportunities or immunities. This could include not only 'affirmative action' through law, but specialist courts, tribunals or procedures for particular kinds of cases or persons (e.g. victimised women, youths, children, employees, or welfare claimants). ${ }^{5}$ Cultural differences have also given rise to legal ideas of special cultural defences and particularised cultural evidence. ${ }^{6}$

At each of these indicatively distinguished levels of practice the underlying aim can be seen as to hold AJ initiatives within the established state legal order - explaining, supplementing it, cashing in its promises of protection, or making it more meaningful to certain groups. ${ }^{7}$ But as changes to law to promote AJ become more extensive (as in a progression through these levels), the visibility in public opinion of the population groups benefiting from them may become higher, and the possibility arises of more controversy over what justice means and who benefits or does not benefit from it. ${ }^{8}$ As certain groups are seen to be given distinct advantages before the law, debate over the extent or justification of these in terms of justice, can become an issue for some other population groups, as has often been seen in controversies around affirmative action strategies.

- A fifth level of AJ initiatives can be characterised as justice-claims made at a tangent to state law. Claims to justice might not address the state legal system at all, if state

4 For example, environmental conditions, as recognised in the access to justice provisions of the Aarhus Convention 1998. Convention on Access to Information, Public Participation in Decision-Making and Access to Justice in Environmental Matters, 25 June 1998, 2161 UNTS 447 (entered into force 30 October 2001.

$5 \quad$ See e.g. Rekha Mirchandani, "What's So Special About Specialized Courts: The State and Social Change in Salt Lake City's Domestic Violence Court" (2005) 39 Law \& Soc Rev 379; Jennifer Thompson, "Who's Afraid of Judicial Activism? Reconceptualizing a Traditional Paradigm in the Context of Specialized Domestic Violence Court Programs" (2004) 56 Me L Rev 407; Suzanna Fay-Ramirez, "Therapeutic Jurisprudence in Practice: Changes in Family Treatment Court Norms Over Time" (2015) 40 Law \& Soc Inquiry 205; Michelle Edgely, "Why Do Mental Health Courts Work? A Confluence of Treatment, Support and Adroit Judicial Supervision” (2014) 37 Intl J L \& Psychiatry 572; Bianca Easterly, "The Ties that Bind Beyond the Battlefield: An Examination of the Diffusion Patterns of Veterans Treatment Courts" (2017) 98 Soc Sci Q 1622; Greg Berman \& John Feinblatt, "Problem-Solving Courts: A Brief Primer" (2001) 23 Law \& Pol'y 125.

6 See e.g. Marie-Claire Foblets \& Alison D Renteln, eds, Multicultural Jurisprudence: Comparative Perspectives on the Cultural Defense (Oxford: Hart, 2009); Richard D Mohr, "Some Conditions for Culturally Diverse Deliberation" (2005) 20 CJLS 87 (legal reasoning should reflect cultural diversity); Anne Phillips, "When Culture Means Gender: Issues of Cultural Defence in the English Courts" (2003) 66 Mod L Rev 510.

7 Thus, access to justice is said to aim at facilitating social inclusion. See e.g. Estelle Hurter, "Access to Justice: To Dream the Impossible Dream?” (2011) 44 Comp \& Intl LJ S Afr 408 at 419, 422.

$8 \quad$ See e.g. D Lambelet Coleman, “Individualizing Justice Through Multiculturalism: The Liberals’ Dilemma” (1996) 95 Colum L Rev 1093 (justice requires balancing of defendant's appeal to cultural evidence against victim's need for equal protection of law). 
legal institutions are seen as unhelpful or irrelevant to achieving justice. So, this more radical AJ activity might be uncommitted as to whether or not justice should (or can) be sought in and through this law. At various times and places the justice-demands of some radical feminists, black liberation movements, religious groups, environmentalists and others have had this character.

At the extreme, AJ activity can be a radical confrontation with existing law, pitting itself against institutions seen as deaf to the justice-demands of marginalised constituencies. Or it can reflect a more passive alienation from and avoidance of law. Some recent empirical research has suggested widespread disaffection from the state legal order among people seeking justice. ${ }^{9}$ Yet, many factors promote as well as challenge faith in state law, and will vary between societies and population groups.

However, if 'voice' (complaint) and 'loyalty' (efforts to access the legal system) seem pointless, the possibility of 'exit' (seeking justice in processes and institutions outside the state legal system) may remain for some marginalised population groups. ${ }^{10}$

- Finally, sixthly, radical AJ in its most extreme form might seek justice through pervasive legal and societal change. In western societies from the second half of the 20th century, AJ movements have usually been located in (or organised to serve) specific population groups, usually minorities, seen as marginalised. But at various times, constituencies of complainants for justice have seen themselves as ('silent') majorities, refused justice by what they see as elites controlling the state and law. Where such constituencies have also seen themselves as capable of dominating society politically, they have sometimes gravitated towards aiming for wholesale transformation of legal institutions seen as deaf to their justice-demands. Today this phenomenon is readily associated with some forms of populism that seek justice for an assumed or localised majority against 'elites' thought of as dominating law and government. ${ }^{11}$

9 Marc Hertogh, Nobody's Law: Legal Consciousness and Legal Alienation in Everyday Life (London: Palgrave Macmillan, 2018) (an empirical study in the Netherlands).

10 Cf Albert O Hirschman, Exit, Voice, and Loyalty: Responses to the Decline in Firms, Organizations and States (Cambridge, MA: Harvard University Press, 1970).

11 Half a century ago Edward Shils defined populism as an "ideology of popular resentment against the order imposed on society by a long-established, differentiated, ruling class which is believed to have a monopoly of power, property, breeding and culture." Quoted in David Fontana, "Unbundling Populism" (2018) 65 UCLA L Rev 1482 at 1487. Nicola Lacey, "Populism and the Rule of Law" (2019) 15 Ann Rev L \& Soc Sci 79, online: Annual Reviews $<$ https://www.annualreviews.org/doi/10.1146/annurev-lawsocsci-101518-042919> referencing much recent literature, describes populism as an approach to politics pitching "a homogeneous 'we the people,' often conceived in ethnic or national terms, embodied in a leader who speaks for and expresses the [people's] will... against a presumptively 'corrupt'... 'elite' (as well as against 'outsider' minorities of various kinds)." The idea of a ruling elite set against a popular majority seems to be a key element in all conceptions of populism. 
This most radical AJ is sometimes presented vaguely ${ }^{12}$ as justice for the $99 \%$ in the face of the tyranny of the 1\%, as in the American and European 'Occupy' movements. Attitudes to law in such contexts are often strongly instrumental: law is seen as a tool to serve the interests of those controlling it. ${ }^{13}$ On such a view, a pragmatic aim of a constituency seeking radical social transformation to achieve justice would be to gain control of law, directly or indirectly, and use it to promote the constituency's interests.

It may be said that part of what has been discussed above is not AJ at all in any form in which it is normally recognised. But the point of envisaging such a spectrum of justice-demands is that their potential range may have few bounds unless these are fixed by law itself. Mainstream AJ movements often do not stop at promoting access to existing law but seek legal reforms to enhance justice well beyond what law currently offers, ${ }^{14}$ so the point at which justice-claims are brought to an end - a brake is put on them - is debatable. It depends on the policies of the regulators (the legal system) and the expectations of the regulated (citizens) in relation to the potential of law and to possibilities of justice.

In practice, expectations are often scaled down both within the legal system and among the regulated. They are constrained within assumptions about the nature of a liberal legal system and its corresponding society. The language in which AJ is often presented makes this clear. 'Public interest law', 'Pro bono' legal practice and 'community legal services': such terms assume a sense of justice rooted in a sense of communal solidarity: a solidarity that requires certain special kinds of law and legal practice aimed at a common, public interest or public good, putting moral responsibilities on lawyers to address the needs of 'have-nots' as well as 'haves', and directing the legal system to communities as much as individuals. Behind all these AJ images is the idea and ideal of a mutually-supporting, solidary society served by a unified, responsive legal system. If the measure of justice is not conclusively given by existing law then the implication is that it is given by needs of social solidarity, and law should adapt as necessary to promote that solidarity. This is, at least, the frequent implicit legitimating social theory of AJ.

The French jurist Emmanuel Lévy, powerfully influenced by Émile Durkheim's sociology, argued that although law depends on the expertise and technicality of lawyers, ultimately it is more dependent on the faith of citizens in the general conceptual structures that law sets up to frame social relations. ${ }^{15}$ Popular conviction and belief in law are like the hot air that keeps a balloon afloat. Without this, the edifice of legality begins to sink. Mainstream AJ movements are surely best seen as efforts to maintain and bolster that conviction and belief in law. They are ultimately about access to the kinds of justice that can secure and preserve faith in law as a framework of solidarity - that is, as Durkheim envisaged, the framework of a society integrated by functional interdependence and moral allegiance; one that, through its law,

12 Jamie Matthews, "Populism, Inequality and Representation: Negotiating “the 99\%” with Occupy London" (2019) 67 Sociological Rev 1018 (stressing tension between (i) an idea of representation of 'the people' based on elusive characterisations of the $99 \%$ and (ii) a non-representational critique of inequality).

13 Brian Z Tamanaha, Law as a Means to an End: Threat to the Rule of Law (New York: Cambridge University Press, 2006) on tendencies towards pervasively instrumentalist views of law.

14 Mauro Cappelletti \& Bryant Garth, “Access to Justice as a Focus of Research” (1981) 1 Windsor YB Access Just ix at x (noting "inevitable tension between the procedural right of access to justice and the substantive goals of many accessoriented reformers.")

15 Emmanuel Lévy, Les Fondements du droit. (Paris: Félix Alcan, 1933); Roger Cotterrell, Living Law: Studies in Legal and Social Theory (Abingdon: Routledge, 2008) at ch 6. 
promotes a degree of public altruism in the sharing of its wealth and, as far as possible, collective participation in shaping the conditions of its citizens' lives. ${ }^{16}$

Yet many popular justice-demands do not reflect such faith-sustaining conceptions of justice seemingly reflected in mainstream AJ. Law, as the 'administration of justice', categorises cases as like or unlike in order to treat them fairly. But popular opinion often entertains justice categories that are not consistently recognised in law, or not legally recognised at all: e.g. rich/poor, employed/unemployed, able/disabled, men/women, LGBT+/straight, urban/rural, and numerous distinctions of class, race and ethnicity. Categorisations do not lose their popular salience even if sometimes imagined (wholly or in part): e.g. elite/non-elite, and 'us'/'others'.

Between law and justice there is mutual dependence but also radical incompatibility. As Jacques Derrida $^{17}$ (and others before him) noted, law is empty unless it appeals to justice as its moral justification and provider of meaning, but justice is infinite and dissolves into innumerable competing perceptions unless fixed by law. Such law calculates and measures, as Lévy emphasised, with apparent solidity and clarity, even if grounded ultimately in a diffuse and sometimes precarious popular faith. ${ }^{18}$

A practical answer to the law-justice conundrum may be to aim in AJ practice for all law to be rooted in the needs of solidarity as Durkheim understood these - that is, the moral integration of all citizens in a cohesive society of interdependence. ${ }^{19}$ Such integration requires, as he recognised and as will be discussed further below, a unifying official value-system demanding society-wide respect for the dignity and autonomy of every individual. ${ }^{20}$ This involves adopting policies to reduce the salience of the most divisive popular justice-comparisons noted above, including action to alter the socio-economic conditions that seem to make these comparisons pressing for some individuals and groups. Then justice-demands might be brought nearer to levels that the administration of justice can handle. By such means justice becomes something practically calculable, in legal terms and in terms of rational social policy.

\section{MORAL DISTANCE}

It has been suggested above that $\mathrm{AJ}$ in its broadest sense, as a practical law-focused goal, means access to ways in which law can meet the justice-expectations of citizens, but in a framework that treats social

16 Roger Cotterrell, Emile Durkheim: Law in a Moral Domain (Stanford: Stanford University Press, 1999); Roger Cotterrell, Law's Community: Legal Theory in Sociological Perspective (Oxford: Oxford University Press, 1994) at 246, 268-9, 332-3.

17 Jacques Derrida, "Force of Law: The Mystical Foundation of Authority" in Drucilla Cornell, Michel Rosenfeld \& David G Carlson, eds, Deconstruction and the Possibility of Justice (New York: Routledge 1992) 3.

18 See references supra note 15.

19 See generally Cotterrell, Emile Durkheim, supra note 16. Numerous Durkheimian insights on relations of justice and solidarity are in Jeffrey C Alexander, The Civil Sphere (New York: Oxford University Press, 2006). See also Floris De Witte, "Transnational Solidarity and the Mediation of Conflicts of Justice in Europe" (2012) 18 Eur LJ 694 (conflicts of justice require attention to forms of solidarity); David Heyd, "Justice and Solidarity: The Contractarian Case Against Global Justice" (2007) 38 J Soc Philosophy 112 (solidarity as underlying conceptual frame for contract-based justice).

20 Émile Durkheim, La Science Social et l'Action (Paris: Presses Universitaires de France, 1970) at ch 10; Cotterrell, Emile Durkheim, supra note 16 at ch 7; Mark S Cladis, A Communitarian Defense of Liberalism: Emile Durkheim and Contemporary Social Theory (Stanford: Stanford University Press, 1992). 
solidarity as an overriding value. But what does 'access' mean in general terms? This involves reconsidering the general relations between citizens and legal systems in liberal democratic society.

Many socio-legal theories conceptualise, in general terms, relations of communication between regulators and regulated - between, on the one hand, officials who create and manage law and, on the other, citizens subject to its jurisdiction. Some are pessimistic about any easy reciprocity between rulers and ruled, or direct communication between law and social fields it attempts to regulate. ${ }^{21}$ One might say that, in this kind of perspective, justice is likely to be seen as something that people must produce for themselves in their various social fields, in terms of the diverse discourses that structure those fields, and according to their own meanings of justice, although state law can contribute impulses towards this selfproduction of justice solutions. But the actual empirical evidence to show an inevitable total inability of law to address directly social spheres it purports to regulate, or to receive directly normative inputs, expectations and information from them is not clear.

Other theories are more optimistic, and - while equally concerned with communication and relations between legal and other discourses - envisage the possibility of direct learning by regulators from the regulated. For example, Philippe Nonet and Philip Selznick's responsive law concept, building on earlier traditions in American sociology and sociological jurisprudence, suggests at least the possibility of selfaware regulation, which can learn, adapt and develop by gaining information - feedback from regulated populations and fields. Thus, social pressures, perceived in the legal system, can be sources of knowledge and opportunities for self-correction. ${ }^{22}$ The basis for such a view of possibilities of communicative interaction is in Selznick's long-propounded idea of implicit values naturally embedded in legal institutions that have inherent purposes.

In such a relatively optimistic perspective, justice, and access to it, might be seen as something to be produced in communicative interaction between regulators and regulated populations. This view of law and society in interaction is also reflected in later theories - often indirectly influenced by Nonet and Selznick - that see legislation as not limited to instrumental aims but potentially also a form of symbolic communication. ${ }^{23}$ As such, it must be responsive law: 'Ideally, the actors in communicative legislation are not situated above society but within it, and they establish a dialogue rather than a monologue. ${ }^{24}$

In legal philosophy, Lon Fuller's well-known 'eight ways to fail to make law' are also, when inverted, ways to enable law most effectively to meet the expectations and capabilities of regulated populations. ${ }^{25}$ To make legislation clear, accessible, non-contradictory, consistent, realistic in its demands, usually non-

21 From the 1980s Gunther Teubner and others, concerned with excessive 'juridification' of social life, urged the use of 'reflexive law' that would empower the regulated to produce their own solutions within facilitative procedural frameworks supplied by this law. When Teubner incorporated the idea of reflexive law in autopoiesis theory, law was now presented as a discursive system with meaning structures that are only self-referential; its messages cannot communicate directly with spheres of social life beyond law; they would inevitably be read (if at all) differently in these spheres. See Gunther Teubner, "Autopoiesis in Law and Society: A rejoinder to Blankenburg” (1984) 18 Law \& Soc'y Rev 291; and for Teubner's recent position, see Gunther Teubner, Constitutional Fragments: Societal Constitutionalism and Globalization (Oxford: Oxford University Press, 2012) at 84-6.

22 Philippe Nonet \& Philip Selznick, Law and Society in Transition: Toward Responsive Law (New Brunswick, NJ: Transaction, 2001) at 77.

23 Nicolle Zeegers, Willem Witteveen \& Bart van Klink, eds, Social and Symbolic Effects of Legislation Under the Rule of Law (Lewiston, NY: Edwin Mellon Press, 2005).

24 Willem Witteveen, "Turning to Communication in the Study of Legislation, in Zeegers et al, ibid 31.

25 Lon L Fuller, The Morality of Law, $2^{\text {nd }}$ ed (New Haven: Yale University Press, 1969) at ch 2. 
retroactive, etc., is not only to make law technically better, fairer and more effective. ${ }^{26}$ It is also to make the relations of regulators and regulated morally worthwhile, so that fidelity to law $^{27}$ and a trusting reciprocity between rulers and ruled is both possible and meaningful.

As noted, all these theoretical approaches centre specifically on communication through and to lawtreated in this paper as communication between regulators and citizens. And this concern, sometimes seen in terms of a metaphor of regulatory 'distance' goes back to the beginnings of socio-legal theory. Early in the $20^{\text {th }}$ century Eugen Ehrlich, the primary pioneer of empirical sociology of law, contrasted what he termed 'living law'28 - authoritative norms regulating everyday life such as that of the farmers in his remote province of the Austro-Hungarian Empire - with the often unknown and locally ineffective official state law created in the culturally and geographically distant imperial capital. But this contrast refers to a remoteness of mutual understanding between rulers and ruled rather than to physical distance. It is a communicative distance.

Communicative distance in regulatory practice has been said to have at least five pernicious dimensions: ${ }^{29}$

- the regulator may lack and fail to acquire knowledge of the specificity of circumstances to be regulated; regulatory knowledge may be too generalised and imprecise;

- second, regulation ${ }^{30}$ may apply or presuppose values at odds with or insensitive to those of regulated populations - its values may seem absolutist to the regulated;

- third, regulatory techniques, shaped without reference to local conditions of their use, may seem crude, limited or poorly adapted to regulatory conditions - inflexible;

- fourth, regulators' receptiveness to or possibilities for obtaining feedback about consequences of regulation may be limited - so it will seem impressionistic; and

- fifth, participation by or direct influence from regulated populations in shaping regulatory policy may be limited - so, the bases of regulation are democratically weak.

However, it is important to note that regulators are almost necessarily 'distanced' to some extent from the regulated. They must take a broad view of the regulatory landscape, surveying whole classes of social

26 Cf Joseph Raz, The Authority of Law: Essays on Law and Morality, 2nd ed (Oxford: Oxford University Press, 2009) at ch 11.

27 Lon L Fuller, "Positivism and Fidelity to Law: A Reply to Professor Hart" (1958) 71 Harv L Rev 630. Fuller's frequent usage of this term is vague, but is taken here to mean the sense that following and applying law can be a worthwhile, purposive human activity.

28 Eugen Ehrlich, Fundamental Principles of the Sociology of Law, translated by W L Moll (New Brunswick, NJ: Transaction Books, 2001) at ch 21.

29 Cotterrell, Law's Community, supra note 16 at 304-5.

30 The term regulation is used in this paper not in a technical sense but to refer to law or law-like normative controls and prescriptions in general. 
relations to provide frameworks of rules to govern these. This is a necessary distancing of perception from the particular towards the general to make regulation sufficiently calculable, broadly applicable, and uniform to be intelligible to those it addresses.

The art of regulating well can be seen as that of judging reliably when communication between regulators and regulated is optimal and when it is inadequate, or blocked. If properly judged (that is, sufficiently distanced to gain regulatory perspective, but not so excessive as to entrench regulatory remoteness) it addresses what Durkheim saw, from a sociological perspective, as a moral need - to regulate society through law in a responsive way that fosters social solidarity. ${ }^{31}$ So, measuring communicative distance raises, as Lon Fuller understood (combining sociological and philosophical insight), moral as well as technical issues. At least this is so, if social solidarity is seen as an aim. It can be said, then, that when communicative distance creates problems of remoteness of law that bear negatively on law's responsibility for promoting solidarity, these are problems of 'moral distance'. ${ }^{32}$

Does democratic accountability, in itself, reduce communicative distance in law? Classical elite theory ${ }^{33}$ has long suggested that all government and regulation is likely to be dominated not by any popular input but by 'circulations' of official elites or relatively stable 'oligarchies' of officials. However, AJ presupposes the possibility of effective communication of demands and the readiness of institutions to which these demands are addressed to listen and respond. But, even where formal democracy is in place, these conditions are surely often not met.

Representative democracy certainly allows society-wide popular access to communicate politically with the state in periodic general elections. Otherwise, access for individuals to particular political representatives (for example, Members of Parliament) may be possible and this can be an important means of securing individual justice. But the ability to vote or to participate in political processes is not in itself necessarily an ability to access justice in the realisation of specific rights or in the resolution of disputes. The perceived limits of representative democratic structures as means of securing effective AJ have inspired suggestions that courts can under certain conditions perform democratic functions better than democratic inputs into legislative policy; ${ }^{34}$ that they can facilitate through the processing of litigation more direct communication of justice-demands between citizens and the state. In such conditions, strategies for more extensive AJ often centre on the possibilities of litigation, rather than in expectations for legislative change.

Such strategies may often be realistic, and the tradition of sociological jurisprudence has strongly emphasised the centrality of the judicial process in securing the protection and balancing of interests. ${ }^{35}$ However, courts are typically pulled in two directions. In one direction, they remain elite institutions -

31 Emile Durkheim, The Division of Labour in Society, translated by WD Halls. (London: Macmillan, 1984).

32 Roger Cotterrell, Sociological Jurisprudence: Juristic Thought and Social Inquiry (Abingdon: Routledge, 2019) at 10$11,228$.

33 Especially that of Vilfredo Pareto, Gaetano Mosca and Robert Michels. For modern reassessment see e.g. John Scott, "Modes of Power and the Re-conceptualization of Elites" (2008) 56 Sociological Rev 25. Harold Lasswell's wide-ranging analysis, "The Study of Political Elites" in Dwaine Marvick, ed, Harold D. Lasswell on Political Sociology (Chicago: University of Chicago Press, 1977) 114, is still instructive.

34 Hugh Collins, "Democracy and Adjudication" in Neil MacCormick \& Peter Birks, eds, The Legal Mind: Essays for Tony Honoré (Oxford: Clarendon Press, 1986) 67; Norman Redlich, "Judges as Instruments of Democracy" in Shimon Shetreet, ed, The Role of Courts in Society (Dordrecht: Martinus Nijhoff, 1988) 149.

35 Cotterrell, Sociological Jurisprudence, supra note 32 at 9-11. 
staffed by a 'circulation of elites' of legal experts monopolising knowledge of the legal system. In another direction, if they aim to become popular tribunals, directly answerable to regulated populations, they risk familiar problems associated with informal justice, particularistic or populist decision-making, and the loosening of a uniform rule of law. Considering the position of courts in terms of the five dimensions of moral distance suggested indicatively above, judges have some advantages (e.g. their case-specific responsibility, and potentially their relative proximity to those seeking justice) and some disadvantages (e.g their more circumscribed ability to research contexts of regulation) as compared with legislatures in optimally setting communicative distance. The criteria of communicative distance apply to them, as to all other regulators in their relations with the regulated populations. But between the extremes of elitist remoteness and populist informalism, courts and court-like decision-making institutions clearly have an important responsibility in promoting $\mathrm{AJ}$ and addressing moral distance.

Whatever institutional structures exist (or do not exist), the concept of moral distance combines many factors that bear on practical possibilities of access of the regulated to the regulators. The existence of representative democratic structures alone does not determine communicative distance. Nor is moral distance necessarily related directly to the legitimacy of particular kinds of authority claims made by regulators. Regulation can be recognised as legitimate while still appearing too remote; moral distance can be problematic in a legal system that, as a whole, receives popular approval. In considering AJ in its widest sense, the idea of moral distance may be the most capacious way to conceptualise general obstacles to seeking justice from the state through its law.

To summarise: this paper has proposed two axes along which to consider a broadened conception of AJ. One axis presents a broad spectrum of types of justice-demands, ranging from very modest to extremely radical. The other generalises, through the concept of moral distance, obstacles to access that arise in processes of legal regulation themselves. The paper has further suggested that implicit in the idea of AJ, as widely understood, is an assumption that the pursuit of justice through law presupposes that justice serves more than individual needs and demands. It is to be understood in a communal framework, so that the pursuit of justice serves also the pursuit of social solidarity, the integration and interdependence of individuals co-existing in society.

As noted above, AJ perspectives tend to presume ideas of community, common or public interest, and 'pro bono publico' practice by which justice-demands of the 'have-nots' become, at least in discourses of socio-legal practice, a concern of the 'haves'. So there is an affinity between underlying justice conceptions in AJ and the pursuit of solidarity in Durkheim's sense. If AJ is sought from and through state law, the context for the state's legal responses is political society as a whole. The object of state legal regulation in pursuit of justice is not just individual claimants but the collectivity of the national political society in its entirety which defines the normal extent of state law's jurisdiction. ${ }^{36}$

36 Roscoe Pound made a similar point in terms of 'interests': "Individual interests are to be secured by law only because and to the extent that they are social interests... the law... secures individual interests because of a social interest in so doing": quoted in Stanford M Lyman, "Toward a Renewed Sociological Jurisprudence: From Roscoe Pound to Herbert Blumer and Beyond" (2002) 25 Symbolic Interaction 149 at 155. But, while Durkheim explains and justifies the concept of solidarity theoretically in terms of the sociological character of modern society, Pound merely postulates the existence of social interests, treating them (and their scope) as self-evident. 
If, then, social solidarity is held out as an ideal for state law to serve, it is first and foremost the solidarity (integration, cohesion) of the entire national political society, rather than of specific groups. For this reason, when AJ movements appeal to the state for justice through state law they must surely presuppose that solidarity in this sense is an overriding value consideration for the state in acceding to their demands. As AJ activity moves along the spectrum towards greater radicalism this consideration may seem pressing so that it that will trump some groups' particular perceptions of justice for themselves.

Reflection on access, in terms of 'moral distance', can also lead directly to a focus on solidarity. As has been seen, this concept encourages a view of $\mathrm{AJ}$ as concerning communication between regulators and regulated, rulers and ruled, or state law and 'living law'. And this presents moral issues as regards relations between lawmakers and regulated populations. It implies an ideal of trust and solidarity as the necessary moral template for these relations. So the concept of moral distance is both descriptive and prescriptive. Descriptively, it points to considerations of proximity or remoteness that in large measure actually determine whether law is likely to be effective, responsive and perceived as related directly to the popular pursuit of justice. At the same time, prescriptively, it indicates certain requirements for satisfactory relations between regulators and regulated. AJ research has long considered empirically many such requirements. The idea of moral distance offers a means of drawing these requirements together conceptually, as empirically and morally inherent in all AJ projects of whatever kind.

\section{MULTICULTURAL AND TRANSNATIONAL ACCESS TO JUSTICE}

It can be suggested that certain wide-ranging contemporary changes in Western law and legal systems make a rethinking of AJ, in the way that this paper has attempted, timely and important. One change is the impact of multiculturalism on law. ${ }^{37}$ The literature on law and culture is vast, although in legal analysis the concept of culture itself remains often opaque. ${ }^{38}$ Much relevant writing focuses on ethnicity and law, or religion and law, prominently including analyses of assertions of Muslim identity among minority groups and resultant issues for Western state law. The European legal literature on the Islamic veil alone, for example, is now huge. Religion and custom are often hard to disentangle in judging state law responses to justice claims of ethnic minorities. And it was noted earlier that, as justice-demands address perceived inequalities between population groups or aim to combat discrimination, they can be pitched at levels in the AJ spectrum where controversy tends to intensify, with heated debates about what justice means, about who is served by particular justice-demands and who may not be.

Some groups pursue justice from a standpoint common within the group, but less well recognised outside it or from a state law standpoint. These groups can be thought of as communal networks having

37 For some indicative recent book-length contributions see e.g. Samia Bano, ed, Gender and Justice in Family Law Disputes: Women, Mediation and Religious Arbitration (Waltham, MA: Brandeis University Press, 2017); Prakash Shah, Marie-Claire Foblets \& Mathias Rohe, eds, Family, Religion and Law: Cultural Encounters in Europe (Abingdon: Routledge, 2014); Livia Holden, ed, Cultural Expertise and Litigation: Patterns, Conflicts, Narratives (Abingdon: Routledge, 2011); Julie Ringelheim, ed, Le droit et la diversité culturelle (Brussels: Bruylant, 2011); Marie-Claire Foblets, Jean-Francois Gaudreault-Desbiens \& Alison D Renteln, eds, Cultural Diversity and the Law: State Responses from Around the World (Brussels: Bruylant, 2010); Ralph Grillo et al, eds, Legal Practice and Cultural Diversity (Abingdon: Routledge, 2009).

38 Cotterrell, Sociological Jurisprudence, supra note 32 at ch 11; Roger Cotterrell, "A Legal Sketch Map of Culture" in Reza Banakar et al, ed, Festskrift till Håkan Hydén (Lund: Juristförlaget, 2018) 107. 
some solidarity among their members; the 'glue' that, to some extent, bonds them together can include, separately or, more often, in combination, (i) shared religious or other beliefs or ultimate values, (ii) economic or other instrumental interdependencies, (iii) common customs, languages, histories, memories, or traditions, or (iv) underlying affective allegiances or rejections. ${ }^{39}$ Moral distance between communal networks and state regulators can be affected in diverse ways by any or all of these. Language and translation problems, entrenched customs, religious convictions or prescriptions, economic conditions, and generalised distrust or alienation can all sometimes create powerful barriers to securing AJ through state law. They can make this law seem remote and inaccessible to members of communal networks; and they can make important characteristics of these networks opaque to state regulators.

How is AJ to be optimised in such circumstances? How far do members of communal networks seek AJ from the state and its law? How far are their justice-demands channelled elsewhere, and why? How far do networks themselves create obstacles to or facilitate AJ through the state legal system? How far do they satisfy their members' justice-demands without the state's aid? These are familiar, much researched questions. Empirical studies in many countries have examined arbitration and mediation institutions created by minority communities themselves to provide AJ in disputes between their members. ${ }^{40}$ Sometimes, important justice-demands are processed entirely inside communal networks without oversight by state law, Sometimes, this processing takes place 'in the shadow' of this law, under its protection and ultimate authorisation (where arbitral decisions are intended to be legally enforceable if necessary). Sometimes it occurs in partnership with state law (as a division of labour in disputeprocessing); sometimes in ignorance or distrust of it. How far is there a responsibility in the state legal system to ensure AJ? Much debate has focused on how far the state should insist on its own AJ processes being operationalised and how far it should remain unconcerned with non-state systems of AJ that do not call on its help, or in any way challenge its jurisdictional prerogatives.

Each of the four kinds of 'glue' mentioned above, which to some extent define communal networks, can intensify moral distance. They can present special obstacles to achieving AJ from the state. So, justice is sought internally in these networks, not only in ethnic and religious minority groups but in many other kinds of communal networks. Justice is sought at a tangent to state law, and so at a tangent to the state's rule of law. Usually there is no denial of the legitimacy of state law but a bypassing of it: an assertion of a different cultural legitimacy authorising internal regulation in the communal network. Then AJ becomes complex and conflicted, because one person's justice can be another's denial of justice. For both the state and the networks it tries to regulate, the need for social solidarity may be of overriding importance in AJ. But this need may be interpreted very differently between them.

I will mention here only very briefly one other major socio-legal change which affects AJ in the way this paper has sought to conceptualise it. This is law's increasing transnational reach. ${ }^{41}$ It is fostered by proliferating international law jurisdictions, especially those attaching rights and obligations to non-state actors; also through extraterritorial effects and assertions of jurisdiction of municipal legal systems, and

39 Roger Cotterrell, Law, Culture and Society: Legal Ideas in the Mirror of Social Theory (Abingdon: Routledge, 2006).

40 See, among many recent examples, e.g. Samia Bano, Gender and Justice in Family Law Disputes (Brandeis University Press, 2017) Latif Tas, Legal Pluralism in Action: Dispute Resolution and the Kurdish Peace Committee (Abingdon: Routledge, 2014).

41 See e.g. Bettina L Kristiansen et al, eds, Transnationalisation and Legal Actors (Abingdon: Routledge, 2019); Cotterrell, Sociological Jurisprudence, supra note 32 at chs 8-10. 
by private entities creating so-called transnational private law. ${ }^{42}$ Much of this regulation having transnational effect is now generically termed transnational law.

In the context of this paper, transnational law's primary significance is that, like some consequences of ethnic or religious multiculturalism, it has the tendency often, though not always, to increase moral distance, to intensify a multifaceted remoteness of regulators from regulated. ${ }^{43}$ As regards state law, there is frequently much moral distance between it and regulated populations within its territorial jurisdiction. However, the perceived remoteness of regulatory activities may be much greater when law is produced entirely outside the society it purports to regulate, or where the regulated have little or no potential contact with the creators of transnational law, who are located beyond the boundaries of their society, or who exist in unknown or obscure regions of international law's regulatory diplomacy.

It can plausibly be argued that extensive cultural pluralism (e.g. as regards beliefs, ethnicity or traditions) and transnational extensions of law are inevitable features of contemporary Western societies, and also that they are in important ways desirable. They indicate new possibilities for social and economic relations, new cultural richness and invigorating diversity, and new opportunities for communication, learning and understanding across national boundaries and within them. At the same time, they present special challenges for AJ. Cultural differences were always a factor in creating moral distance, but over the past half century they have grown in significance. So, the cultural pluralism associated with minority ethnic and religious groups intensifies in some respects the moral distance between state law and some categories of citizens who seek AJ. At the same time, it encourages manifestations of AJ 'in the shadow of' state law, or existing 'at a tangent to state law'.

Equally, the proliferation of transnational law - through international trade treaties, new international jurisdictions, extraterritorial legal effects and extradition processes - sometimes clearly intensifies the sense of law's remoteness from those it purports to address. Here moral distance takes on a new dimension. The issue is not necessarily about the 'reflexivity' or 'responsiveness' of state law to the AJ demands of the citizens of the state, or about communication, trust and fidelity linking citizens and their state. It is sometimes about the remoteness of regulation that does not emanate from the citizens' own state, or does not do so directly. Then the AJ relation may seem not to be between citizen and state, but between citizens and even more remote regulators, with the state as, at best, an intermediary. The citizen's own state can seem powerless, even irrelevant, indeed incapable of responding to AJ demands because it has no (or inadequate) control over the legal processes to which citizens appeal.

This is not necessarily an issue of the legitimacy of regulatory regimes, about which the regulated may or may not have a view, or enough knowledge to take a view. Nor is it fundamentally an issue of democracy although the rhetoric of democratic accountability is often invoked in discussion. At base, it is more fundamental and immediately practical. It is an AJ issue centred on realistic possibilities of communication, responsiveness, and trust between rulers and ruled.

Here a special and obvious link between populism and AJ exists. The most radical forms of AJ are those that have given up on the state and seek justice despite it; or they seek AJ not by asking for it from the state but by aiming to transform the state - to push it in entirely new regulatory directions, to demand a justice that the state as currently existing can never be expected to provide. This is certainly the situation

42 Gralf-Peter Calliess \& Peer Zumbansen, Rough Consensus and Running Code: A Theory of Transnational Private Law (Oxford: Hart, 2010)

43 Cotterrell, Sociological Jurisprudence, supra note 32 at 132-7. 
when law and government are seen as controlled by 'elites' incapable of recognising the justice-demands (or even the life conditions in which these demands are made) of 'the people'.

This situation is surely likely to be intensified when these elites are thought of as outside or not tied to the society that the regulated inhabit. ${ }^{44} \mathrm{So}$, popular perceptions of a moral distance so great that it makes regulators and regulated appear utterly alien to each other can be, in part at least, an effect of the intensification of law's transnational reach through law-making processes largely hidden from even the imagination of regulated populations. Yet, where AJ claims relate to transnational socio-economic relations, and state law is not in a position to offer justice through its law, it is transnational law itself, in some of its many forms that may be the necessary vehicle for redress and the only available addressee of AJ demands. Hence the need to find ways of building forms of transnational solidarity to underpin this law and of developing devices to recognise, analyse and address the indicative, previously noted, five dimensions of moral distance as far as possible in transnational legal processes.

\section{THE STATE'S RESPONSIBILITY FOR ACCESS TO JUSTICE}

The experience of cultural pluralism and transnationalism shows that AJ demands do not go away if the state fails to satisfy them. They often find other outlets - for example, in communal dispute resolution processes such as religious arbitration tribunals, in 'private legal systems' such as those devised to regulate international sport, ${ }^{45}$ or in transnational processes in trade, finance or digital technology. Or they remain radical, utopian claims that find no outlet for satisfaction. But, for the foreseeable future, most of the pressing AJ claims are likely to continue to be addressed initially to the state, and the state must somehow take a principled view as to what kinds of claims for justice it will recognise.

This is a matter of ultimate values to guide state attitudes to $\mathrm{AJ}$; that is, values to give practical meaning to the idea of justice in the legal system, so that the administration of justice goes beyond merely the fair administration of positive law, but does not collapse in an infinity of possible meanings of justice. ${ }^{46}$ Mainstream AJ demands for access to knowledge of state law or for procedural and substantive legal changes to make the benefits of the rule of law available to all citizens are surely easily encompassed in some such principled view. Existing mainstream AJ practice, with its invocations of 'community', 'public interest' and 'pro bono', as previously emphasised, points to a conception of justice going beyond isolated individual claims and recognising a wider public or social interest. Thus, the recognition of AJ as a concern of the legal system reflects a value of communal solidarity. And, if the concept of moral distance is useful as an organising idea, this is because it emphasises not merely technical obstacles to securing justice but also a moral relationship that incorporates the regulators and the regulated in a single community, structured by some degree of trust and links of reciprocity that make fidelity to law worthwhile. Thus

44 See e.g. Antonin Cohen, "Constitutionalism without Constitution: Transnational Elites Between Political Mobilization and Legal Expertise in the Making of a Constitution for Europe (1940s-1960s)" (2007) Law \& Soc Inquiry 109; Harry W Arthurs, "Globalization of the Mind: Canadian Elites and the Restructuring of Legal Fields" (1997) 12 CJLS 219 (influence of transnational legal elites).

45 See e.g. Lorenzo Casini, "The Making of a Lex Sportiva by the Court of Arbitration for Sport" (2011) 12 German LJ 1317.

46 Cf Ralph Henham, Sentencing Policy and Social Justice (Oxford: Oxford University Press, 2018) (explicit state embrace of ultimate values of dignity and autonomy needed to support administration of criminal justice). 
moral distance signals threats to the solidarity that a general aspiration to AJ can be understood to presuppose.

The requirements of solidarity - that is, of the need to integrate society in meaningful patterns of interdependence among its members - present important challenges and responsibilities for state law. Durkheim's morally-infused sociology of law explores this issue in depth ${ }^{47}$ but so do many philosophies of law in different ways. Gustav Radbruch, for example, develops the idea that law's responsiveness to justice claims is to be shaped and guided by a society's overarching social purposes which inform the way law has to interpret justice. ${ }^{48}$ While justice is a crucial value which law should serve, justice itself has to be given content from unifying social purposes recognised as valid in their time and place, purposes that make the idea of law practically meaningful in the context of particular society. One interpretation of this is to say that the need for solidarity in society as a whole sets limits to the otherwise unlimited demands for justice that might be pressed on law.

In a Durkheimian perspective, a particular modern value system is needed to underpin or promote solidarity. This will insist on equal recognition of the autonomy and human dignity of every individual. ${ }^{49}$ So, it sets itself against discriminations and inequalities demanded in the name of justice by some individuals or groups where these actually infringe ideas of universal individual dignity and autonomy. For Durkheim, this value system is an essential requirement for society-wide solidarity because it makes possible mutual recognition and interdependence between individuals. But it is a minimal value system. It does nor prescribe life-styles or specify the meaning of justice for individual cases or claims. It merely asserts that, from the state's perspective emphasising the needs of solidarity across the political society that it purports to regulate, all justice-demands must presuppose at base a certain understanding of the moral equality of standing of all individuals, both those claiming justice and those against whom it is claimed.

Following this values-oriented approach, it appears that state law cannot treat any communal networks as regulatory 'black boxes'; it must ultimately have some (limited) input into the practical meaning of justice within them. But, conversely, communal networks must have an input into the state's regulatory processes. Durkheim envisaged the state not as commanding, but as learning and co-ordinating, ${ }^{50}$ while at the same time firmly insisting on the value system of individual autonomy and human dignity.

It is not necessary to elaborate such indicative ideas further here. It may be enough to say that AJ, generalised as an idea across the whole range of current socio-legal conditions, is a search for justice through state law and, up to a point, beyond this law. But, crucially, while AJ claims can be located across a very wide spectrum of justice-demands, only part of that spectrum can be recognised in state law and the state must operate with firm and viable principles to set the cut-off points for justice claims.

Durkheimian understandings of an obligation of the state to promote and facilitate social solidarity provide one such set of principles. They are justified not philosophically but sociologically in terms of ultimate non-negotiable values of individual dignity and autonomy that are appropriate to the promotion

47 See generally, Cotterrell, Emile Durkheim, supra note 16; Carol J Greenhouse, "Durkheim and Law: Divided Readings over Division of Labor" (2011) 7 Ann Rev L \& Soc Sci 165.

48 Gustav Radbruch, Legal Philosophy, 3rd ed (1932) reprinted in The Legal Philosophies of Lask, Radbruch and Dabin, translated by Kurt Wilk (Cambridge, MA: Harvard University Press, 1950) 43.

49 See especially Cladis, Communitarian Defense of Liberalism, supra note 20.

50 Cotterrell, Emile Durkheim, supra note 16 at 154-7, 160-3. 
of society-wide solidarity, as well as the solidarity of communal networks within the political society. It follows that, from this perspective, the wide-ranging search for AJ can be recognisable by the state and its legal institutions only up to the point at which it remains compatible with the needs of solidarity.

These needs are, this paper has suggested, already implicit in mainstream practices of AJ. And they unify the diverse considerations about access to state institutions that are signalled in the concept of moral distance. They indicate one way of conceptualising both practical possibilities and limits to AJ in conditions where aspirations to justice are increasingly varied, and arise in a widening diversity of intranational, national and transnational contexts. 